\title{
Development of the Double Digest Selective Label (DDSL) Typing Technique and Its Application to Staphylococcus aureus Epidemiology \\ (Pembangunan Label Terpilih Cernaan Berganda (DDSL) Teknik Penjenisan dan Pemakaiannya dalam Epidemiologi Staphylococcus aureus)
}

\author{
V. TERLETSKIY, V. TYSHCHENKO, D.A. MYRZAKOZHA*, O.O. ZHANSERKENOVA, \\ Y.S. USSENBEKOV \& NURBEK L. ADAEV
}

\begin{abstract}
Bacterial typing is a key technology in human and veterinary medicine, community health, consumer protection and in agricultural research. The importance of the development of epidemiological tracking tools is underlined by numerous outbreaks of diseases due to bacterial pathogens. Particularly important is tracing pathogen dissemination in 'real time' i.e. to use a fast typing technique to distinguish between clonally related (epidemic) strains and unrelated (sporadic) strains. The aim of the research was to develop a fast discriminatory molecular typing technique-double digest selective label (DDSL) for Staphylococcus aureus isolates and to compare typing data with that obtained by pulsed-field gel electrophoresis. In this new typing method, large DNA fragments are produced with a restriction enzyme commonly used for PFGE but are trimmed by a second enzyme to a size which can be separated on a conventional agarose gel within a short period of time. Selective labelling of a subset of the numerous restriction fragments gives a distinct banding pattern for each isolate. Discriminatory power obtained with DDSL calculated over two different sets was higher than that of pulsed-field gel electrophoresis. Clusters of identical isolates were further resolved to unique DDSL strains. Two combinations of restriction enzymes for DDSL technique has been proposed with approximately equal discriminatory power. It has been demonstrated that DDSL approach is a fast, discriminatory alternative to other typing techniques suitable for short-term epidemiological studies.
\end{abstract}

Keywords: DDSL; DNA; electrophoresis; epidemiology; fingerprinting; Staphylococcus aureus

\section{ABSTRAK}

Penjenisan bakteria adalah teknologi utama dalam perubatan manusia dan haiwan, kesihatan masyarakat, perlindungan pengguna dan penyelidikan pertanian. Kepentingan pembangunan alat pengesanan epidemiologi digariskan oleh pelbagai wabak penyakit yang disebabkan oleh patogen bakteria. Adalah amat penting untuk mengesan penyebaran patogen secara 'masa nyata' iaitu untuk menggunakan teknik penjenisan pantas untuk membezakan antara strain berkaitan klon (wabak) dan strain tidak berkaitan (setempat-setempat). Kajian ini bertujuan untuk membangunkan teknik penjenisan diskriminasi molekul pantas- label terpilih cernaan berganda (DDSL) bagi pengasingan Staphylococcus aureus dan untuk membandingkan penjenisan data dengan yang diperoleh melalui elektroforesis jel medan denyut. Dalam kaedah penjenisan baru ini, cebisan DNA yang besar dihasilkan dengan enzim sekatan yang biasanya digunakan untuk PFGE tetapi dikemaskan oleh enzim kedua kepada saiz yang boleh dipisahkan dengan jel konvensional agarosa dalam tempoh masa yang singkat. Pelabelan terpilih sebahagian daripada cebisan sekatan yang banyak memberikan corak banding yang berlainan bagi setiap pencilan. Kuasa diskriminasi yang diperoleh dengan DDSL dikira menggunakan dua set yang berbeza adalah lebih tinggi daripada elektroforesis jel medan denyut. Kelompok pencilan seiras telah dileraikan kepada strain DDSL yang unik. Kombinasi dua sekatan enzim untuk teknik DDSL telah dicadangkan dengan kuasa diskriminasi yang hampir sama. Ia telah menunjukkan bahawa pendekatan DDSL adalah pantas dan diskriminasi alternatif kepada lain-lain teknik penjenisan yang sesuai untuk kajian epidemiologi jangka pendek.

Kata kunci: DDSL; DNA; elektroforesis; epidemiologi; pencapjarian; Staphylococcus aureus

\section{INTRODUCTION}

Outbreaks of infectious diseases pose a serious threat to human health and animal welfare. Strain discrimination obtained by molecular typing techniques has become an essential tool for monitoring and preventing the transmission of pathogens such as Staphylococcus aureus in various settings (Boers et al. 2011). The emergence and spread of methicillin-resistant $S$. aureus has become an increasing problem worldwide (Al-Zahrani et al. 2011.). The importance of epidemiological tracking tools is underscored by numerous studies of Staphylococcus aureus transmission. In practice, it is particularly important to be able to trace pathogen dissemination in 'real time' and this depends on the use of a fast typing technique which 
is available on site and which has sufficient precision to discriminate between clonally related (epidemic) and unrelated (sporadic) strains and to follow the chain of transmission and localize pathogen reservoirs (Francois et al. 2005). Pulsed field gel electrophoresis (PFGE) is currently the 'gold standard' typing method for shortterm micro-epidemiological investigations. PFGE is suitable for many different bacterial species but each application requires careful optimization. For example, PFGE analysis of Staphylococcus aureus (Blanc 2004) is currently based on the rare-cutting restriction enzyme, SmaI, which is accepted as being the most informative of several alternatives (Trindade et al. 2003). On the other hand, some studies indicated that methicillin resistant ST398 strains of S. aureus often exhibit non-typeability in SmaI pulsed-field gel electrophoresis (Feßler et al. 2010). This non-typeability can be explained by the presence of a novel C5-cytosine methyltransferase gene (sauST398M) in the ST398 isolates (Argudin et al. 2010). Recent studies suggested using Cfr9I in place of SmaI to overcome the problem (Argudin et al. 2010; Bosch et al. 2010). In some bacterial species, individual strains cannot be typed by PFGE because of the expression of endogenous endonucleases (Koort et al. 2002). A higher level of discrimination than that afforded by PFGE analysis would be beneficial in some studies (Willse et al. 2004) and in other cases, it would be a great advantage to be able to perform an analysis in less than several days which is typical for PFGE typing (Mitani et al.2005). A further disadvantage of PFGE is the specialized equipment it requires, which is not available in many settings. Multilocus sequence typing (MLST) is a practical alternative but only for long-term studies because its level of discrimination is not sufficient to use in short-term settings where sequence differences are reduced (Fakhr et al. 2005). MLST is relatively expensive (Foxman et al. 2005) and screens only a preselected subset of conserved genomic sequences whereas whole genome typing methods (like PFGE) screen sites throughout the bacterial genome and are thus more reliable for studying pathogen diversity (Melles et al. 2004). In summary, none of the currently existing techniques for typing pathogenic bacteria fully meets all requirements for dependable short-term epidemiological analysis and there is an urgent demand for a rapid, cost effective alternative.

The objective of this article was to demonstrate the potential of new fast typing technique, double digest selective label (DDSL), which was initially developed to identify clinical isolates of Pseudomonas aeruginosa, another important nosocomial bacterial species (Terletskiy et al. 2008). In this report, the method has been adapted for analysis of Staphylococcus aureus chicken and turkey isolates.

The underlying concept of the DDSL approach is that the large macrorestriction fragments currently produced by the rare cutting restriction enzyme can be reduced in size by simultaneous digestion with a second frequently cutting restriction enzyme to give a large number of smaller fragments that can be rapidly separated on a conventional agarose gel. The 3'-recessed ends of cuts produced by the rare cutter are suitable for end-labelling (Terletskiy et al. 2010) with conventional Taq DNA polymerase whereas the blunt ends of cuts produced by second trimming enzyme are not labelled. The product of this single tube/single buffer digestion/labelling reaction is a characteristic set of labeled fragments suitable for rapid electrophoretic separation and detection. The result is a 'barcode' banding pattern which identifies each bacterial isolate and is the key to rapid epidemiological analysis. An additional advantage of DDSL is that individual bands are significantly sharper and there is a potential to resolve more bands than is possible with PFGE.

\section{MATERIALS AND METHODS}

\section{STRAINS AND DNA ISOLATION}

The set of isolates included 28 isolates collected from chicken and turkey meat and product from four regions of Germany - Bavaria, Baden Wurttemberg, Lower Saxony and Rhineland-Palatine (Feßler et al. 2011).

Staphylococcal chromosomal DNA was extracted from 3 mL overnight cultures in BHI (brain heart infusion) growth medium. Bacterial lysis was accomplished with lysostaphin and sodium dodecylsulfate (SDS). DNA isolation was based on a single round of conventional phenol-chloroform extraction followed by isopropanol precipitation, washing in $70 \%$ ethanol. DNA was dissolved in 50 microliters of distilled water.

\section{DIGESTION / LABELLING}

Simultaneous digestion and labelling of the bacterial genomic DNA $(0.5-1 \mu \mathrm{g})$ was performed with 5 units of rare cutting enzyme, 5 units of a frequent cutting enzyme, 0.2 units of Taq polymerase and $0.2 \mu \mathrm{M}$ of biotinylated dCTP or Dig-dUTP. Two combinations of restriction enzymes were tested:XhoI/BsuRI and Bsp120I/KspAI. All restriction enzymes were from MBI Fermentas, St. Leon-Rot, Germany. Bio-dCTP was from Invitrogen GmbH, Karlsruhe, Germany and Dig-dUTP - from Roche (Roche Diagnostics GmbH, Mannheim, Germany). Technically, set up of the reaction can be described as follows: 14 microliters of distilled water, 2 microliters of an appropriate restriction buffer, 3 microliters of DNA and 1 microliter of the enzyme mix.

For the enzyme combination Bsp120I/KspAI biotinylated nucleotide (Bio-dCTP) was included whereas combination of XhoI/BsuRI required Dig-dUTP. The reaction time was $60 \mathrm{~min}$ and the incubation temperature was $37^{\circ} \mathrm{C}$. Reaction buffers were selected on the basis of compromise for the best reaction conditions for both restriction enzymes. For XhoI/BsuRI we used buffer R, for Bsp120I/KspAI -buffer B (both buffers are from MBI Fermentas). The nature of recessed ends produced by 
Bsp120I is such that in order to get Bio-dCTP incorporated in fill-in reaction the latter should contain dGTP nucleotide. The nucleotide was added directly to enzyme pre-mix to a final concentration of 500 micromoles.

With multiple bacterial isolates it was technically convenient to prepare a pre-mix containing the required amounts of two restriction enzymes, Taq DNA polymerase and Bio-dCTP (Dig-dUTP). In this case, the protocol is significantly simplified, requiring only the addition of $1 \mu \mathrm{L}$ of this mixture to each sample of chromosomal bacterial DNA in an appropriate buffer. The pre-mix is stable for at least 1 month at $-20^{\circ} \mathrm{C}$ (storage for a longer period has not been tested).

\section{ELECTROPHORESIS}

Prior to electrophoresis, the reaction product was desalted using reusable microcolumns filled with G50 Sephadex ${ }^{\circledR}$ matrix (Amersham Biosciences, Freiburg, Germany). Electrophoretic conditions were as follows: $1 \times \mathrm{TAE}, 20 \mathrm{~cm}$ $0.8 \%$ agarose gel, $2 \mathrm{~V} / \mathrm{cm}$ voltage. Conventional 'submarine' agarose gel electrophoresis required approximately $18 \mathrm{~h}$ for satisfactory separation of digested and labelled DNA fragments (overnight electrophoresis).

\section{TRANSFER}

Once electrophoresis was completed, the separated fragments were directly transferred to a neutral nylon membrane (GE Healthcare). The DDSL technique does not involve hybridization so that denaturation and neutralization of the DNA in the agarose gel is not required. Transfer to a nylon filter was performed in a deonized water using a vacuum blotter (Amersham) for $40 \mathrm{~min}$.

\section{DETECTION}

After transfer, the biotinylated DNA fragments were crosslinked to the membrane by UV-irradiation then visualized by application of either Streptavidin-AP conjugate (1703554, Bio-Rad, Munich, Germany) or Anti-Dig antibody (Roche Diagnostics GmbH, Mannheim, Germany) followed by a colorimetric reaction based on the alkaline phosphatase. Briefly, the filter was preincubated for $10 \mathrm{~min}$ in blocking solution (0.1 M maleic acid, $0.15 \mathrm{M}$ sodium chloride, $1 \times$ Roche blocking reagent ${ }^{\mathrm{TM}}$ - Roche Diagnostics $\mathrm{GmbH}$, Mannheim, Germany -, pH7.5) and then treated with Streptavidin-AP or Anti-Dig antibody diluted 1:3000 in the blocking solution. Unbound conjugate was removed by two $10 \mathrm{~min}$ washes with maleic acid buffer $(0.1 \mathrm{M}$

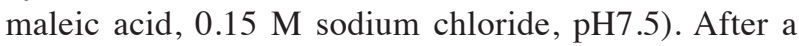
short equilibration in alkaline buffer $(0.1 \mathrm{M}$ Tris, $0.1 \mathrm{M}$ sodium chloride, $\mathrm{pH} 9.5$ ), the filter was placed in a plastic dish containing developing solution consisting of the two chromogenic substrates NBT and BCIP (MBI Fermentas) in alkaline buffer. Colour development was normally complete within 15 min (Bio-dCTP tag) or $4 \mathrm{~h}$ (Dig-dUTP tag). Images were captured with a flatbed scanner and saved as TIFF files for further evaluation.

\section{SIMULATION OF DDSL AND SUGGESTION TOOL}

A suggestion tool was also created, which allows selecting endonuclease combinations capable to generate a band pattern by DDSL. All data available through this tool has been pre-computed. The procedure to search this database is simple: User must select the genera of the prokaryote, the visualization method for bands (capillary electrophoresis or agarose gel) and the labelled nucleotide to be used in the experiment. In the first step, the service will show a table with endonucleases yielding fragment ends that may be labelled with the selected nucleotide. Those enzymes can be combined with additional endonucleases to yield bands by DDSL. After selection of one of the enzymes in this first table, a second table is shown containing all endonucleases which may be combined with the previous one. In the table the number of theoretical bands for each sequenced genome is shown.

\section{RESULTS}

Various restriction enzymes were evaluated on the basis of their cutting frequencies and DDSL was assayed online prior to wet experiments with the simulation program created during this work. Besides cutting frequencies, other criteria were taken into account including buffer compatibility for a double digestion, the ability to produce highly specific cuts even at high excess over template DNA and optimal fragment/band distribution in an agarose gel. According to the enzyme selection program developed by Bikandi et al. (2004), XhoI (rare cutter) and BsuRI (frequent cutter) produces 1372 and 77 cuts in chromosomal DNA of the Mu50 strain of $S$.aureus, respectively. Taking into account the genome size of this bacterial species (approximately 2.9 $\mathrm{mbp}$ ), the average size of detected fragments after double digestion with theserestriction enzymes is expected to be approximately $1000 \mathrm{bp}$. More frequently cutting enzymes produced too many small fragments which ran off the gel under the conditions used. Similar consideration was paid to the other enzyme combination. Bsp120I produces 110 cuts, combination of Bsp120I/KspAI theoretically results in 112 fragments in the size range of 400-25000 base pairs. The average fragment size is expected to be $1800 \mathrm{bp}$.

In general, wet chemistry experiments confirmed these theoretical predictions and proved the usefulness of the in-silico tool for generating DDSL banding patterns with reasonable number of well distributed DNA fragments suitable for comparative analysis. For example, Figures 1 and 2 show typical DDSL patterns obtained on a set of 28 S.aureus isolates of poultry origin with application of XhoI/BsuRI and Bsp120I/KspAI enzyme combinations, respectively. The former combination is based on digoxigenin chemistry while the latter make use of biotin label. Signal from biotinylated fragments (Bsp120I/Ksp AI enzymes and Bio-dCTP) builded up within 15 min and was quite strong, whereas $\mathrm{XhoI} / \mathrm{BsuRI}$ enzymes requiring DigdUTP for a fill-in reaction resulted in a weaker bands even after $4 \mathrm{~h}$ of the development. 


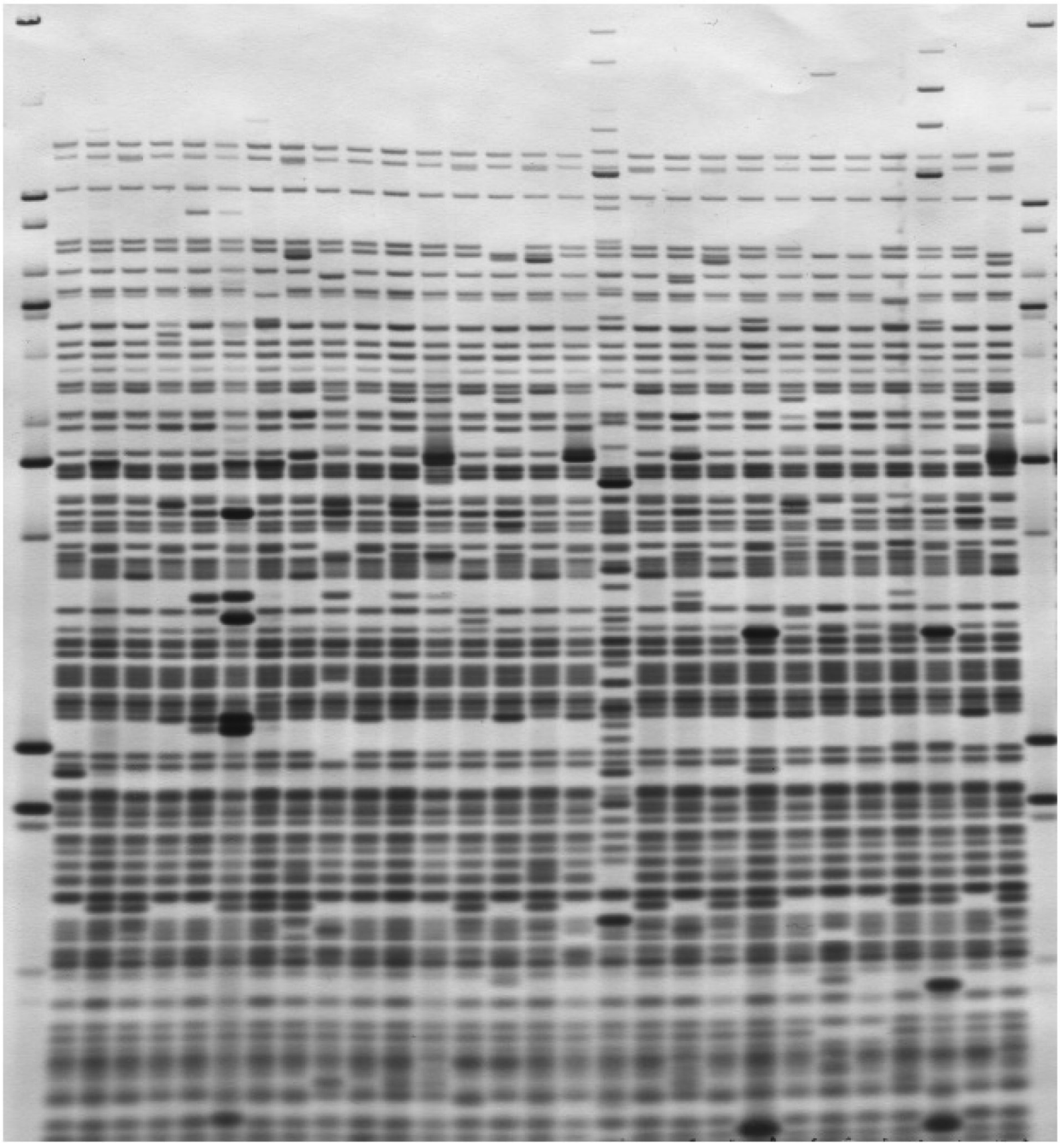

FIGURE 1. DDSL genotyping of a set of 28 S. aureus isolates (chicken - isolates 1-8, turkey - isolates 1t-22t) with restriction enzymes XhoI/BsuRI

DDSL data obtained on these isolates with both enzyme combinations were quite close. XhoI/BsuRI approach resulted in 26 types and index of discrimination based on Simpson's index of diversity (Table 1). Bsp120I/KspAI typing showed in 24 types and index of discrimination D $=0.9886$. There was a pair of identical isolates revealed by both approaches - no. Chi-3 and Tur-15 (type $3 \mathrm{a}$ ). Isolates no- Tur- 8 and Tur- 10 were identical by $X h o I / B s u R I$ approach (type $3 \mathrm{~b}$ ) and they were slightly different by Bsp 120I/KspAI typing (types 3a and 3b). Isolates Tur-7 and
Tur-21 were identical by $B s p 120 \mathrm{I} / K s p$ AI typing (type 14 ) and they were different by 2 bands in XhoI/BsuRI enzyme combination (15a and $15 b)$.

\section{DISCUSSION}

Biotinylated fragments (application of Bio-dCTP in a reaction) are developed much faster than fragments tagged with digoxigenin (application of Dig-dUTP). This can be explained by stronger chemical bonds formed between 


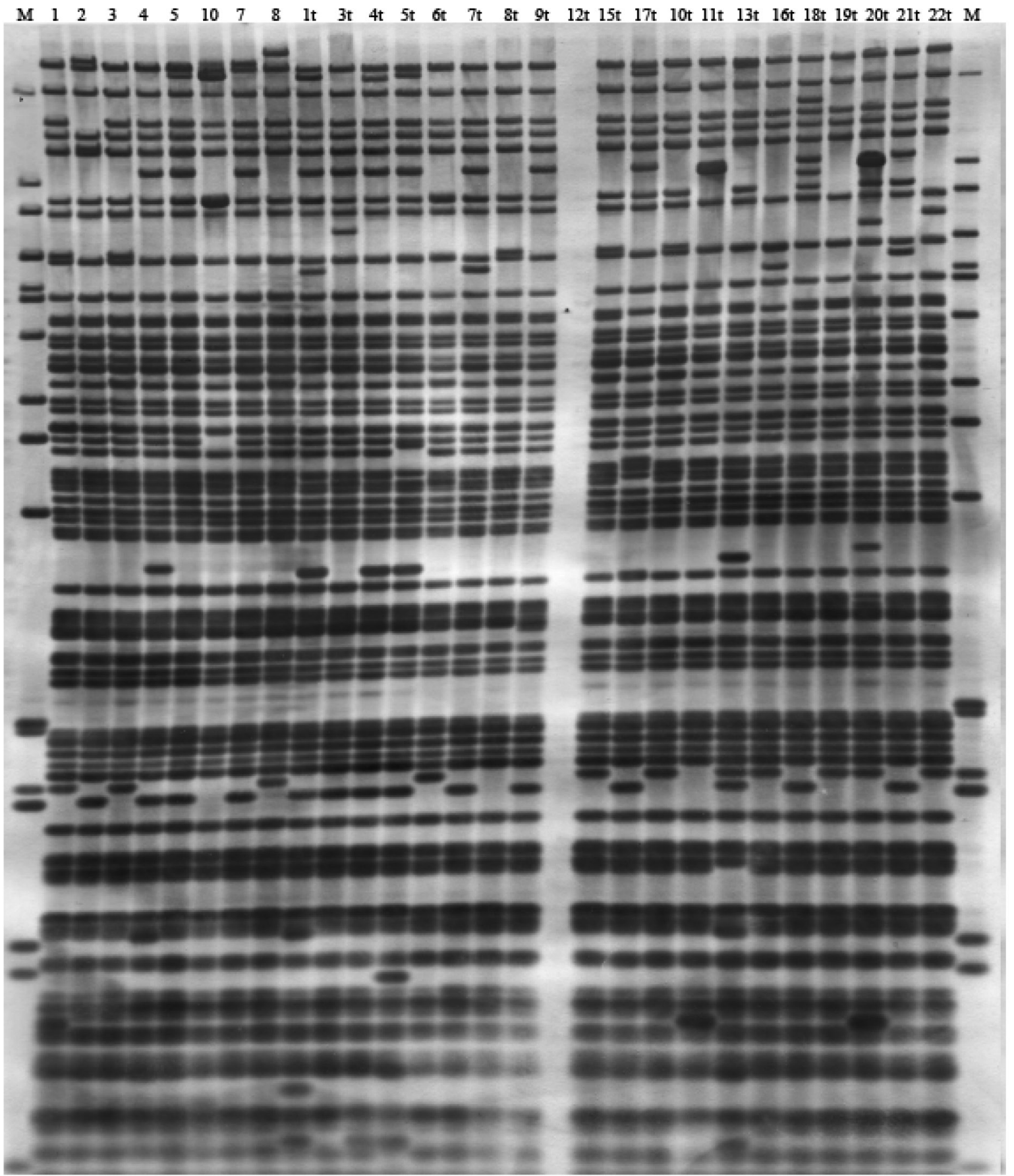

FIGURE 2. DDSL genotyping of a set of $28 \mathrm{~S}$. aureus isolates (chicken - isolates 1-8, turkey - isolates 1t-22t) with restriction enzymes Bsp1201/KspAI. 12t - failure

streptavidin and biotin in comparison with bonds between digoxigenin and its antibodies. Originally, we tried to use Cfr9I/HaeII and Cfr9II/BsuRI combinations but there was virtually no signal. These combinations worked good in our early studies with other sets of $S$. aureus isolates (not published). Explanation for this is methylation pattern acquired by the strains in our study. It is well documented that ST398 strains are resistant to digestion with SmaI enzyme but can be digested with $C$ fr $9 \mathrm{I}(3,11,16)$. According to our experience, some ST398 isolates were resistant to $C$ fr9I digestion. Neoisoschizomer of ApaI which has been often used for macrorestriction digestion (Feßler et al. 2010) and XhoI as rare cutters proved to be efficient also with DDSL approach.

One explanation for the differences between PFGE and DDSL fingerprinting methods is that they do not sampling exactly the same genetic alterations. In that sense, they can be thought of as complementary rather than competing methods. The main polymorphisms sampled by PFGE typing are due to point mutations in the restriction 
TABLE 1. Comparison of genotyping results obtained by PFGE and DDSL techniques on a set of 28 S. aureus ST 398 chicken and turkey isolates(BA, Bavaria, BW, Baden Wurttemberg, LS, Lower Saxony, RP, Rhineland-Palatine)

\begin{tabular}{|c|c|c|c|c|}
\hline Sample origin & Isolate & Location & $\begin{array}{l}\text { DDSL type } \\
\text { Xhol/BsuRI }\end{array}$ & $\begin{array}{c}\text { DDSL type } \\
\text { Bsp120I/KspAI }\end{array}$ \\
\hline Chicken meat & Chi-1 & Germany, LS & 1 & 1 \\
\hline Chicken meat & Chi-2 & Germany, LS & 2 & 2 \\
\hline Chicken meat & Chi-3 & Austria & $3 a$ & $3 a$ \\
\hline Turkey product & Tur-15 & Germany, LS & $3 a$ & $3 a$ \\
\hline Chicken meat & Chi-4 & Germany, LS & 4 & $4 a$ \\
\hline Chick. meat & Chi-5 & Germany, LS & 5 & $5 \mathrm{a}$ \\
\hline Chick. meat & Chi- 10 & Germany, LS & 6 & 6 \\
\hline Chicken product & Chi-7 & Germany, LS & 7 & $5 b$ \\
\hline Chicken product & Chi-8 & Unknown & 8 & $7 \mathrm{a}$ \\
\hline Turkey meat & Tur-10 & Germany, LS & $3 b$ & $3 a$ \\
\hline Turkey product & Tur-8 & Germany, RP & $3 b$ & $3 b$ \\
\hline Turkey meat & Tur-11 & Germany, LS & 9 & 8 \\
\hline Turkey meat & Tur-13 & Unknown & 10 & 9 \\
\hline Turkey meat & Tur-16 & France & 11 & 10 \\
\hline Turkey meat & Tur-18 & Italy & 12 & 11 \\
\hline Turkey meat & Tur-19 & Germany, LS & 13 & 12 \\
\hline Turkey meat & Tur-20 & Germany, LS & 14 & 13 \\
\hline Turkey meat & Tur-21 & Germany, RP & $15 \mathrm{a}$ & 14 \\
\hline Turkey product & Tur-7 & Austria & $15 b$ & 14 \\
\hline Turkey meat & Tur-22 & Germany, BW & 16 & 15 \\
\hline Turkey product & Tur-1 & Germany, BW & 17 & 16 \\
\hline Turkey product & Tur-3 & Germany, BW & 18 & 17 \\
\hline Turkey product & Tur-4 & Germany, BW & 19 & 18 \\
\hline Turkey product & Tur-5 & Germany, LS & 20 & 19 \\
\hline Turkey product & Tur-6 & Germany, RP & 21 & $7 b$ \\
\hline Turkey product & Tur-9 & Germany, BA & 22 & $4 \mathrm{~b}$ \\
\hline Turkey product & Tur-12 & Germany, BW & 23 & - \\
\hline \multirow[t]{2}{*}{ Turkey product } & Tur-17 & Austria & 24 & 20 \\
\hline & & & $\mathrm{D}=0.9947$ & $\mathrm{D}=0.9886$ \\
\hline
\end{tabular}

cutting sites for the restriction enzyme and large genomic rearrangements (phage mobilization and large insertions/ deletions). The main sources of polymorphism for DDSL typing are point mutations in the restriction cutting sites for the pair of restriction enzymes plus a contribution attributable to small genomic rearrangements (small insertions/deletions). In view of the large genome of bacteria, it is not surprising that different typing methods produce different typing clusters particularly for closely related bacterial strains. For instance, it is well known that PFGE typing performed on the same set of bacterial isolates with different PFGE enzymes may produce different groupings using standard algorithms for genetic relatedness (Davis et al. 2003). Some reports have indicated an absence of correlation between PFGE and MLST typing while others indicated higher discriminatory power with PFGE than with MLST (Foley et al. 2004). Screening a larger number of bands and thus larger number of nucleotide sequences can be advantageous in terms of resolving power. Limitations inheriting in agarose gel analysis prevent the detection of all DDSL fragments produced as a result of double digestion and it is expected that the application of capillary electrophoresis or microfluidic devices would bring out the ultimate discrimination potential of DDSL.

An interesting feature of DDSL is that it is not sensitive to incomplete digestion with the rare cutting enzyme. In preliminary tests, progressively lower amounts of this enzyme were included in the reaction mix and the specificity of banding patterns remained constant even though there was a progressively lower signal. In contrast, 
complete digestion with trimming enzyme was critical for generating reproducible patterns. This observation can be explained by the fact that virtually all long fragments are cut with the frequently cutting trimming enzyme and detected fragments have one end from the rare cutter and the other from the trimming enzyme. Loss of some rare cutter fragment ends due to incomplete digestion does not change the observed fragment sizes which are mostly determined by the trimming enzyme.

\section{CONCLUSION}

Our data suggest that DDSL typing can be successfully applied for short-term epidemiological studies with Staphylococcus aureus when the time is critical and in laboratories where specialized equipment for pulsed field electrophoresis is not available. The DDSL typing technique has a potential for application to other bacterial species. Online simulation software was developed which allows performing in silico experiments prior to wet ones and a suggestion tool allows the selection of suitable combination of endonucleases for all up-to-date sequenced prokaryotic species. This tool is of great interest for those researches willing to apply DDSL fingerprinting to species that has not been searched previously with this technique.

\section{ACKNOWLEDGEMENTS}

This work was supported by the NATO Science for Peace Program (SpS) \# CBP.EAG.CLG 984259 by providing fellowships to V. T. and V.T.

\section{REFERENCES}

Al-Zahrani, I.A., Hamson, C., Edge, D., Collins, J., Perry, J.D., Raza, M., Gould, K. \& Harwood, C.R. 2011. SmaI restriction site-based multiplex PCR for typing of hospitaland community-acquired Staphylococcus aureus. J. Clin. Microbiol. 49: 3820-3828.

Argudin, M.A., Fetsch, A., Tenhagen, B.A., Hammerl, J.A., Hertwig, S., Kowall, J., Rodicio, M.R., Kasbohrer, A., Helmuth, R., Schroeter, A., Mendoza, M.C., Braunig, J., Appel, B. \& Guerra, B. 2010a. High heterogeneity within methicillin-resistant Staphylococcus aureus ST398 isolates, defined by Cfr9I macrorestriction-pulsed-field gel electrophoresis profiles and spa and SCCmec types. Appl. Environ. Microbiol. 76: 652-658.

Argudin, M.A., Rodicio, M.R. \& Guerra, B. 2010b. The emerging methicillin-resistant Staphylococcus aureus ST398 clone can easily be typed using the Cfr9I SmaI-neoschizomer. Lett. Appl. Microbiol. 50: 127-130.

Bikandi, J., San Millán, R., Rementeria, A. \& Garaizar, J. 2004. In silico analysis of complete bacterial genomes: PCR, AFLP-PCR, and endonuclease restriction. Bioinformatics 22: 798-799.

Blanc, D.S. 2004. The use of molecular typing for epidemiological surveillance and investigation of endemic nosocomial infections. Infect. Genet. Evol. 4: 193-197.

Boers, S.A., van Ess, I., Euser, S.M., Jansen, R., Tempelman, F.R. \& Diederen, B.M. 2011. An outbreak of a multiresistant methicillin-susceptible Staphylococcus aureus (MR-MSSA) strain in a burn centre: the importance of routine molecular typing. Burns. 37: 808-813.

Bosch, T., de Neeling, A.J., Schouls, L.M., van der Zwaluw, K.W., Kluytmans, J.A., grundmann, H. \& Huijsdens, X.W. 2010. PFGE diversity within the methicillin-resistant Staphylococcus aureus clonal lineage ST398. BMC Microbiol. 10: 40.

Davis, M.A., Hancock, D.D., Besser, T.E. \& Call, D.R. 2003. Evaluation of pulsed-field gel electrophoresis as a tool for determining the degree of genetic relatedness between strains of Escherichia coli O157:H7. J. Clin. Microbiol. 41: 1843-1849.

Fakhr, M.K., Nolan, L.K. \& Logue, C.M. 2005. Multilocus sequence typing lacks the discriminatory ability of pulsedfield gel electrophoresis for typing Salmonella enterica serovar Typhimurium. J. Clin. Microbiol. 43: 2215-2219.

Feßler, A.T., Kadlec, K., Hassel, M., Hauschild, T., Eidem, C., Ehricht, R., Monecke, S. \& Schwatz, S. 2011. Characterization of methicillin-resistant Staphylococcus aureus isolates from food and food products of poultry origin in Germany. Appl. Environ. Microbiol. 77: 7151-7157.

Feßler, A., Scott, C., Kadlec, K., Enricht, R., Monecke, S. \& Schwarz, S. 2010. Characterization of methicillin-resistant Staphylococcus aureus ST398 from cases of bovine mastitis. J. Antimicrob. Chemother. 65: 619-625.

Foley, S.L., Simjee, S., Meng, J., White, D.G., McDermott, P.F. \& Zhao, S. 2004. Evaluation of molecular typing methods for Escherichia coli $\mathrm{O} 157: \mathrm{H7}$ isolates from cattle, food, and humans. J. Food Prot. 67: 651-657.

Foxman, B., Zhang, L., Koopman, J.S., Manning, S.D. \& Marrs, C.F. 2005. Choosing an appropriate bacterial typing technique for epidemiological studies. Epidemiol. Perspect. Innov. 2: $10-17$.

Francois, P., Huyghe, A., Charbonnier, Y., Bento, M., Herzig, S., Topolski, I., Fleury, B., Lew, D., Vaudaux, P., Harbarth, S., van Leeuwen, W., van Belkum, A., Blanc, D.S., Pittet, D. \& Schrenzel, J. 2005. Use of an automated multiple-locus, variable-number tandem repeat-based method for rapid and high-throughput genotyping of Staphylococcus aureus isolates. J. Clin. Microbiol. 43: 3346-3355.

Koort, J.M.K., Lukinmaa, S., Rantala, M., Unkila, E. \& Siitonen, A. 2002. Technical improvement to prevent DNA degradation of enteric pathogens in pulsed-field gel electrophoresis. $J$. Clin. Microbiol. 40: 3497-3498.

Melles, D.C., Gorkink, D.F.J., Boelens, H.A.M., Snijders, S.V., Peeters, J.K., Moorhouse, M.J., van der Spek, P.J., van Leeuwen, W.B., Simons, G., Verbrugh, H.A.\& van Belkum, A. 2004. Natural population dynamics and expansion of pathogenic clones of Staphylococcus aureus. J. Clin. Invest. 114: 1732-1740.

Mitani, N., Koizumi, A., Sano, R., Masutani, T., Murakawa, K., Mikasa, K. \& Okamoto, Y. 2005. Molecular typing of methicillin-resistant Staphylococcus aureus by PCR-RFLP and its usefulness in an Epidemiological study of an outbreak. Jpn. J. Infect. Dis. 58: 250-252.

Terletskiy, V., Tyshchenko, V., Martinez-Ballesteros, I., Garaizar, J. \& Bikandi, J. 2010. Validation of double digest selective label database for sequenced prokaryotic genomes. Bioinformatics 26: 417-418.

Terletskiy, V., Kuhn, G., Francioli, P. \& Blanc, D.S. 2008 Application and evaluation of double digest selective label (DDSL) typing technique for Pseudomonas aeruginosa hospital isolates. J. Microbiol. Methods 72: 283-287. 
Terletskiy, V., Michael, G.B. \& Schwarz, S. 2004. Subtracted restriction fingerprinting - a new typing technique using magnetic capture of tagged restriction fragments. FEMS Immunol. Med. Microbiol. 41: 1-8.

Trindade, P.A., McCulloh, J.A., Oliveira, G.A. \& Mamizuka, E.M. 2003. Molecular techniques for MRSA typing: Current issues and perspectives. Braz. J. Infect. Dis. 7: 32-43.

Willse, A., Straub, T.M., Wunschel, S.C., Small, J.A., Call, D.R., Daly, D.S. \& Chandler, D.P. 2004. Quantitative oligonucleotide microarray fingerprinting of Salmonella enterica isolates. Nucleic Acids Res. 32: 1848-1856.

V. Terletskiy \& V. Tyshchenko

All-Russia Research Institute of Farm Animal Genetics and Breeding

Moscowskoye sh. 55a, 196625, St. Petersburg-Pushkin

Russia
D.A. Myrzakozha*, O.O. Zhanserkenova \& Y.S. Ussenbekov Kazakhstan National Agrarian University

Abaj str. 8, Almaty

Kazakhstan

Nurbek L. Adaev

Chechen Research Institute of Agriculture

Lenin str. 1, Gikalo village, Groznij district, 366021

Russia

*Corresponding author; email: myrzakozha@yahoo.com

Received: 31 December 2012

Accepted: 13 August 2014 